\title{
English As A Medium of Instruction in School of Arts
}

\author{
Yulduz Sherbekova,yulduz.sherbekova@mail.ru \\ Sabina Makhmudova, nebesanomer7@mail.ru \\ Nasiba Normuradova, nnormuradova@gmail.ru \\ Ozoda Nuraliyeva, nuraliyevaozoda@mail.ru \\ Mokhiya Beknazarova,mokhiya.n.@mail.ru
}

\begin{abstract}
Nowadays, there are a lot of programs, projects and associations for developing the English language in Uzbekistan. To be specific, one of these associations is Uzbekistan teachers of English Association (UzTEA) which is organized in 1996 and has 14 branches in Uzbekistan. The main goal of this association is to enhance the role of teaching and learning English and to provide English teachers with necessary equipment and materials in Uzbekistan. UzTEA big resource center sin Samarkand and Fergana branches in 2002 according to the goals of this association. Therefore this association in order to exchange ideas and practices conducts different forums, systematic programs of methodology and linguistics, conferences and couces for developing the English language in Uzbekistan (Qobilova, 2018). Next in order, after implementing the decree of the first president of Uzbekistan in 2012, there is organized NSFLA system on the basis CEFR standard in Uzbekistan, which helps to English teachers to get CEFR standard levels. One more program is opening American Webster University in Uzbekistan in 2018, which offers student centered learning environment and prepares BA and MA students accor ding to TESL program.
\end{abstract}

Keywords: Music, teaching materials, assessment, evaluation, Material development, proposal, planning, teachers' and students' needs, curriculum, education centers, English for specific purposes, English as a foreign language, standards, cooperation.

Received: 08.12.2020 Accepted: 13.01 .2021

Published: 03.02.2021

\section{Introduction}

A great deal of them are proposed and being conducted based on the needs of EFL and ESL teachers and English learners (ELs). But not all the language problems are solved, there we can meet some which are the matters of the question. One of these problems is the lack of certified, trained and qualified special teachers who know English in Uzbekistan. One central proposal to promote in this LPP proposal is the case in Ecuador where was established teacher educational reform from 2008. It is an innovative teacher preparation which is described as "a work in progress" (Kuhlman \& Serrano, 2017, p.96). At present, there is no system to mentor such kind of teachers or provide any type of continuing professional development in English, except language proficiency in Uzbekistan. To be specific, there are not any music teachers who know even basic English in Jambay, Samarkand. I have been at school of music and art № 10, which needs some qualified English teachers for conducting classes on special musical instruments, literature of music and solfeggio. So, the problem is English teacher preparation issue on specific purposes.

As Martin (2008) considered that it is indispensable for the teachers to be supplied with the required skills and knowledge of the sociolinguistic and multilingual contexts where they live and work. As it mentioned before, there is not any music teacher who knows English in Jambay, but a lot of parents and students in the school of music and art №10 want classes to be taught in English. The first reason is that English is developing in our country in high levels nowadays, so the requirements for this language is also enhancing. Secondly, there are a lot of students in this school who participated in the world music competitions where needed the English language in order to communicate, to know their partners better. Here, the language contact with different language situations in international concerts, music competitions can be one of the factors for necessity of the English language (Mihalicek\&Wilson, 2011, p.486).

This proposal is organized to open an education center for training music teachers in English in the school of music and art №10 in the region of Jambay in Samarkand. This school is situated in the center of Jambay and here we can observe a multilingual society because there study students of different nationalities like Uzbeks, Russians, Tajiks and Tatars. Due to this factor, this school has its own policy of using the Russian language in the territory of the school. Almost all students and teachers cope with this policy even though major students did not know Russian when they started studying in this school. In 
addition, the cultural content of English is also considerable here, because this language is different from other languages in that it 'extends' the meaning of particular words beyond the culture specific connotations where the international demands made on it \{Lyons [quoted in Street (1984: 78)]\}. To some extent, this proposal will be effective for this school, because a majority of the teachers here do want to learn the English language for better results in their work, which is defined after an interview with teachers from this school. As Barry (2008) considered one of the worthiest ways that linguistics is correlated with teaching in the reality of language policy. As it is known from Barry's thoughts, "teachers are often policy makers or have an impact on policy decisions". Their influence can be seen either in their classroom or in the larger system which they work, so in this proposal music teachers will be able to influence their students in both sides conducting music lessons in English and within these lessons help them to learn English better and provide English speaking environment. In the other hand, it is important to open an education center in the work place. As Hasanova (2007) described the situation in Uzbekistan, teachers in order to attend optional professional development training for finding both the finance and the time were responsible themselves, even this issue continues till nowadays, so in this proposal this problem is also solved.

The proposal in the first range is formed at micro level which is a realization of two trends like examining of local level and addressing language problems with a more critical ethnographic or discourse oriented focus ( Kheng \& Baldauf, 2011, p.936). As Kaplan (2011) defined 'language policy' as " a body of ideas, laws, regulations, rules and practices intended to achieve the planned language change in the society, group or system" this proposal can be an effective means for developing the English language in educational system of Uzbekistan. After finishing the timeline of the pilot project, this proposal can be implemented in all music schools of Uzbekistan.

Current article is about training music teachers in English and increase the number of special English teachers in Uzbekistan, music teachers in English in rural regions. These teachers are involved from the school of music and art №10. They are 34 and this quantity is worthy for increasing the number of Music teachers in English. There are some objectives which be considered in order to reach essential goals. To open an education center for professional development in the school of music and art №10. This education center will serve as a basis for further development of this pilot project. To teach these teachers intensively in a year. Essentially, intensive teaching program is appropriate for teachers, because they think about their jobs more than learning language. To invite Native English speaker musicians. Native English speaker professionals can be very productive and optimal for exchanging ideas and content knowledge in English. To conduct lessons according to CEFR standard and co-teach with native English musicians. As CEFR standard is established in Uzbekistan from 2012, teaching according to this standard is very comfortable for ESL/EFL teachers. To give "English Musician" certificates for graduators of the course. These certificates can serve as diploma from this intensive course and will help teachers to find out better jobs not only in Uzbekistan but also in other related countries. To provide topic vocabulary classes for chosen sphere, because content vocabulary is very essential in order to conduct music lesson in English. To organize different webinars and conduct chosen classes with using Kahoot. As IT technologies are developing day by day in the world, using these techniques for languages learning are optional. To set up WI-FI and English speaking zone in this center; To open Telegram channels for the actors; To organize morning and evening groups essentially to the time-table of the teachers. Outlined objectives can lead to the following outcomes:

1) Teachers will get at least B1 level according to CEFR standard during this intensive course;

2) Teachers will be able to exchange their ideas and thoughts with foreign specialists;

3) English learner teachers will be certified as "English Musicians" after finishing the course.

Inventory for this school is given below:

\begin{tabular}{|l|l|}
\hline Available recourses & Quantity \\
\hline $\begin{array}{l}\text { Rooms from musical school } \\
\text { №23 for conducting } \\
\text { classes) }\end{array}$ & 2 \\
\hline Desks & 20 \\
\hline Chairs & 42 \\
\hline White boards & 2 \\
\hline
\end{tabular}




\begin{tabular}{|l|l|}
\hline Bookshelves & 2 \\
\hline $\begin{array}{l}\text { Telegram Channel ( for } \\
\text { discussing additional } \\
\text { questions and problems) }\end{array}$ & 1 \\
\hline
\end{tabular}

For this proposal will be needed: 2 experienced ESL/ EFL teachers for teaching Basic English and developing learners' proficiency due to CEFR standard; 1-2 Native English speaker musicians for exchanging ideas and practices in English. Projectors for conducting classes with Power Point Presentations; Speakers for developing listening skills; Copy machines for copying essential handouts, materials etc.; Computers for lesson planning, printing, presentations, webinars etc.; nWI-FI zone for conducting lesson with the help of webinars and the cite Kaahoot.com;

As this proposal is intended for training music teachers in English, it is possible to propose for additional percentage of salary of music teachers who know English at least at B1 level according to CEFR standard which exists in Uzbekistan. By the decree of the first President of Uzbekistan Islam Karimov in 2012, English teachers who have B2 level according to CEFR standard can be paid for additional $30 \%$ and who have $\mathrm{C} 1$ level- $50 \%$ in rural areas. It is a good chance for English teachers to be motivated and stimulated like this and such kind of rewards can be very preferable for music teachers too. English teachers who got one of the CEFR standard levels can be the member of UzTEA. According to the State statistics of Uzbekistan there are more than 1000 members of this association and who takes active part in the pojects and programs of this association can be awarded with "Teaching English Excellence Award". The Award is funded by British Council. Subsequently, participant teachers of this proposal can be the members of UzTEA in order to be more active in the learning process of the English language.

In the other hand, it is known that there are a lot of music schools in all countries of Central Asia. Due to the Central Asian statistics, there are 301 music schools In Uzbekistan, 182- in Kazakhstan, 92- in Turkmenistan, more than 50 in Tajikistan, more than 30 in Kyrgyzstan. All these schools need professional musicians in English. Subsequently, this proposal can be implemented in such kind of schools in the future. project.

Suggested timeline for implementation of this proposal is 13 months. It is a time for a pilot

\begin{tabular}{|c|c|}
\hline $\begin{array}{l}\text { I phase } \\
\text { (1 month) }\end{array}$ & Diagnostic tests, organizing schedule and other preparations. \\
\hline $\begin{array}{l}\text { II phase } \\
\text { months) }\end{array}$ & Getting A1, A2 and B1 levels \\
\hline $\begin{array}{l}\text { III phase } \\
\text { (3 months) }\end{array}$ & $\begin{array}{l}\text { Classes by native speaker specialists and co-teaching with English proficient teachers, } \\
\text { because specialists know their profession in English better than English teachers, so co- } \\
\text { teaching here is an effective way. }\end{array}$ \\
\hline
\end{tabular}

\section{Aspects.}

a) Suggested target language skills and projects:

- Listening skills ( listening to songs with music, watching and listening to the videos and movies which are preferable for both: visual and audio-lingual learners);

- Speaking skills ( for improving learner's fluency where intended activities are: group works, discussions, information-gap, consensus building, rating activities etc.);

- Writing skills ( for improving learner's accurate writing, in order to be able to describe and analyze all aligned music topics in written form, to be able to take notes and make lesson plans in English for music classes);

- Reading skills (for developing learner's types of reading skills as intensive and extensive reading of music materials, its literature, theory; jigsaw, scanning and skimming reading in order to be informed about all necessary knowledge of music and its literature in English);

- Topic vocabulary due to professions ( for being able to enrich fluency in this sphere);

- Professional projects in English (Power Point presentations about music and its literature in English)

\section{b) Assessments which are required and recommended.}

As this proposal is intended for academic setting, assessments should be addressed here. Firstly, it is preferable to optimize diagnostic tests before beginning the course in order to be more familiar with the learners. 
To develop learners level on the CEFR in this proposal is used own assessments which are:

- Informal and formal assessments;

For formal assessment there will be included portfolios, presentations based on the topics, reflection journals. For informal assessment can be included all teacher's preferences which are intended for developing learner's basic English and integrated skills.

- Formative and summative assessments;

Formative assessment can provide information about teaching and learning activities during the classes, which can be adapted due to the needs of the language learners (Black \& William, 1998, p.140). For formative assessment will be included all tasks and activities during the classes according to the lesson plans and be considered learners' participation. For summative assessment will be included a criterion test according to CEFR standard and general examination of music and its literature in English. After passing this test and exam learner teachers will be certified as English musicians.

- Analytical assessment;

\section{c) Actors:}

- Music and Art school №10 in Jambay. This actor will provide this proposal with building for education center, with available recourses like boards, desks, chairs, bookshelves.

- Qualified EFL or ESL teachers will develop materials for teaching and conduct English classes.

- Native Speaker Musicians also will develop special lesson plans and materials for teaching music and its literature in English cooperating with EFL or ESL teachers.

- Government officials (Ministry of education of Uzbekistan and British Council) will support this proposal with necessary educational settings and books. Also financial support for paying teachers' salaries.

- $\quad$ Samsung company in Uzbekistan will provide the education center with necessary technologies such as projectors, speakers, copy machines, computers and air conditioners.

- $\quad$ The newspaper "Jomboy Tongi" (Morning in Jambay) will always give information about the news of this center.

d) Funding

\begin{tabular}{|l|l|l|}
\hline Needed recourses & Quantity & Cost \\
\hline Projectors & 3 & $300 \$$ \\
\hline Copy machines & 2 & $250 \$$ \\
\hline Computers & 3 & $600 \$$ \\
\hline Speakers & 2 & $30 \$$ \\
\hline Air conditioners & 3 & $450 \$$ \\
\hline WI-FI zone foreign & 3 months & $200 \$$ (for the whole year) \\
\hline Books and others rent for & 1 & $200 \$$ \\
\hline $\begin{array}{l}\text { Apartment } \\
\text { specialists }\end{array}$ & & $300 \$$ \\
\hline Total & & $2330 \$$ \\
\hline
\end{tabular}

\begin{tabular}{|l|l|l|l|l|}
\hline & $\begin{array}{l}\text { Quantity } \\
\text { teachers }\end{array}$ & $\begin{array}{l}\text { Salary } \\
\text { (per month) }\end{array}$ & Period of working & Total salary \\
\hline ESL or EFL teachers & 2 & $300 \$$ & 12 months & $7200 \$$ \\
\hline Foreign specialists & 1 & $2000 \$$ & 3 months & $6000 \$$ \\
\hline Total & $13200 \$$ & & \\
\hline
\end{tabular}

As proposal takes a long period for implementation, here is possible the usage of both one-time and ongoing funding due to the decisions of involved foundations. 
They are:

- Ministry of education of Uzbekistan ( responsible for the budget of EFL and ESL teachers, books);

- British Council ( responsible for the budget of foreign specialists);

- $\quad$ Samsung company in Uzbekistan ( responsible for technologies).

\section{Conclusion}

It is important to mention here that there are different available recourses as material recourses and human recourses. To conclude this article it is possible to reallocate essential resources. To begin with human recourses, we can say that that reallocation of existed professionals in Music and Art school is possible here. For example, the headmaster of the school can also work in this position for the education center as a part time job. Teachers who will get certificates from this pilot project in the future will be able to train other musicians, so here financial recourses also can be economized for further implementation of this proposal.

For material recourses reallocation is done due to the classrooms and educational equipment. Subsequently, 2 rooms from the school of art and music №10 will be used for conducting English classes. These rooms were used for solfeggio lessons before. All educational equipment: desks, chairs, bookshelves will be used for this pilot project. They were used for solfeggio classes too. A big concert hall of this school intended for different concerts, shows and meetings will be available to be used for various meetings, big presentations which can occur during this pilot project.

For reallocation of time there are used no solfeggio days. Essentially, solfeggio lesson days are Tuesday, Thursday and Saturday; and English classes day will be Monday, Wednesday and Friday. According to this teacher training program, the schedule of English classes will be established due to profile teachers' timetable. There will be organized two shift groups: Morning and evening groups.

\section{References:}

Barry, A.K (2008). Linguistic perspectives on language and education. Upper Saddle River, N.J: Pearson/Merrill Prentice Hall [Barry] Chapter 1_ The linguistic perspective (pp.2-8).

Black, P. J., \& William, D. (1998). Inside the black box: Raising standards through classroom assessment. Phi Delta Kappan, 80(2), 139-148.

Chua Siew Kheng, C. \& Baldauf, Jr., R.B. (2011). Micro language planning. In E. Hinkel (Ed.), Handbook of research in second language teaching and learning: Volume 2 (936-951). New York: Routledge.

Decree of the President of the Republic of Uzbekistan "On measures to further improve foreign language learning system" №1875 from December10,2012.

Hasanova, D. (2007). Teaching and learning English in Uzbekistan. English Today, 23(1), 3-9.

Kachru, B. (1990). World Englishes and applied linguistics. World Englishes, 9(1), 3-20. Edited $\quad$ by R. Quirk and H. Widdowson. Cambridge: Cambridge University Press.

Kaplan, R.B. (2011). Macro language planning. In E. Hinkel (Ed.),Handbook of research in second language teaching and learning: Volume 2 [924-925] New York: Routledge.

Mihaliček, V. \& Wilson, C. (eds.). (2011). Language files: Materials for an introduction to language and linguistics (11th ed.). Columbus, OH: Ohio State University Press.

Natalie Kuhlman, Elisabeth Serrano (2017). 5. Teacher Educational Reform: The Case in Ecuador. In Lía D. Kamhi-Stein, Gabriel Díaz Maggioli, Luciana C. de Oliveira (Eds.), English Language Teaching in South America: Policy, Preparation and Practices (pp. 95- 108). Bristol, Blue Ridge Summit: Multilingual Matters.

Qobilova, G., (2018). Uzbekistan Teaching English Association. Retrived from ～http://www.ustea.uz. 